\title{
CHILDHOOD, SUSPECT CLASSIFICATIONS, AND CONCLUSIVE PRESUMPTIONS: THREE LINKED RIDDLES
}

\author{
LAURENCE H. TRIBE*
}

This article is about three puzzles. Each of them, taken alone, seems all but impossible to solve. But each contains some pieces that fit well into the whole, so that the still larger puzzle made by all three together looks at least a bit more soluble.

\section{Puzzle I: Childhood}

The first puzzle revolves about a pair of social facts: that everybody begins life in a special, relatively helpless state; but that not every society recognizes as a distinct stage of life the period we call childhood. It has been fashionable recently to perceive childhood as a cultural artifact, an invention of the industrial revolution. ${ }^{1}$ Linked to this perception is a notion that treating children as "special" tends to oppress them, so that we would do well to abandon our fixation on age as an independently significant variable. But our experience of life-of being and having and watching children-seems to tell us otherwise. It tells us that something about childhood is, for us, both inescapable and priceless, and that the effort to "escape from childhood"-to borrow the title of a leading tract in the "children's liberation" movement ${ }^{2}$ - must, in the end, be anything but liberating.

\section{Puzzle II: Suspect Classifications}

We tend to distrust people with power over those they regard as different or inferior. In the fundamental law of our society, we create safeguards against the abuse of such power. We express those safeguards largely through antimajoritarian institutions that view with suspicion all public

\footnotetext{
* Professor of Law, Harvard University. A more systematic development of some of this article's themes appears in Tribe, Structural Due Process, 10 Harv. Civ. Rights-Civ. Lib. L. Rev. 269 (1975).

1. The argument has been advanced that "children" did not exist in medieval societythat "childhood" as a temporal phase of personal development separating infancy from adulthood is largely an invention of the industrial mind and of the school and family institutions to which industrialization gave rise. See P. Aries, Centuries of Childhood $21-22$ (R. Baldick transl. 1962).

2. J. Holt, Escape From Childhood (1974). See also R. Farson, Birthrights (1974). Both books are provocative, but neither is very helpful in thinking through the really perplexing issues raised.
} 
actions tending to burden "discrete and insular minorities." 3 But if the system of coalitions and elections seems to be functioning properly at the political level, it is at least arguable that no such powerless minorities should exist; and if one assumes inadequate coalition-formation and electoral representation, then every group that finds itself disadvantaged by a public choice potentially qualifies for antimajoritarian solicitude as "discrete" and "insular." 4 Children ideally illustrate the difficulty. If the universality of the childhood experience (all of us were children once) could guarantee empathy from adult lawmakers despite the absence of children from legislative assemblies, there would be no occasion to regard children as an isolated and unrepresented minority in need of special protection; but if adults instead look with contempt at a stage they have "outgrown"5 and will never re-enter, then every privilege withheld by legislators or administrators from the young must become a source of suspicion. ${ }^{6}$ Yet, judicially treating age-based classifications as suspect for this reason is easily reconcilable only with the ideal of an ultimately "child-blind" society. ${ }^{7}$ Aspiring to a society that gives children a special place, instead of one that ignores their distinctiveness, does not fit well with a demand that all public actions setting children apart be halted unless specially justified to the satisfaction of a suspicious arbiter. ${ }^{8}$.

3. United States v, Carolene Prods. Co., 304 U.S. 144, 152-53 n.4 (1938) (dictum).

4. "It would hardly take extraordinary ingenuity for a lawyer to find insular and discrete' minorities at every turn in the road." Sugarman v. Dougall, 413 U.S. 634, 657 (1973) (Rehnquist, J., dissenting).

5. See DeMause, The Evolution of Childhood, I Hist. Child hoon Q. 503, 508-27 (1974).

6. Compare discriminations against the old. Like at least some discriminations against youth (those that increase the likelihood of long-term disabilities, as in the case of juvenile delinquency proceedings), discriminations against the very old may appear, from the perspective of those imposing them, to be of more limited duration than they appear from the perspective of those who experience their impact, particularly since a disability is most burdensome if one cannot look forward (ever) to losing it. It is true that, as to discriminations against the aged, there exists at least the political safeguard that legislators and administrators might expect someday to experience the consequences of their current choices to withhold benefits from the old. But if persons are regarded as poor representatives of their own future selves (as they well might be), then the efficacy of this safeguard is dubious at best. See note 79 infra.

7. In the somewhat analogous case of racial classification, it may be nothing but the longterm ideal of a "color-blind" Constitution, Plessy v. Ferguson, 163 U.S. 537, 559 (1896) (Harlan, $\mathrm{J}$, dissenting), that makes strict judicial scrutiny of laws discriminating against racial minorities acceptable as something other than insulting paternalism; and it may well be only the "colorblind" ideal that makes "benign" racial discrimination tolerable as an intermediate step toward ultimate neutrality.

8. As a temporary tactic, "thinking of minors as a class which may be victimized in [distinct] ways," Kaimowitz, Legal Emancipation of Minors in Michigan, 19 WAYNE L. Rev. 23, 45 (1972), might be helpful; but as a longer-term strategy, thinking in this way could run counter to the deepest wellsprings of the movement for justice to children, a movement that proceeds less from a sense of the historically-rooted oppression of a group properly classified as such than from a sense that, in some settings, classification as a substitute for thought may itself work grave injustice-as when a person's status as infant, child, or adolescent is invoked as a sufficient justification for allowing others to speak, while the person most intimately affected remains unheard and often essentially unseen. 


\section{Puzzle III: Conclusive Presumptions}

A tenaciously-held principle of many in our society is that each person should be treated as an individual rather than as a statistic or as a member of a group-particularly of a group the individual did not knowingly choose to join. At the same time, the ideal we have come to revere as the "rule of law" points away from individualized treatment and suggests instead the decision of particular cases in accord with general rules, promulgated in advance, that identify as dispositive certain readily ascertainable and separable facets of the "total" situation. Again, the tale is well told by children. To assume that this seven-year-old is unfit to vote, to work, to choose his or her own school, simply because most persons of like age have certain characteristics is to condemn by association, by statistical stereotype, by what the Supreme Court in a number of recent decisions has invalidated as "conclusive presumptions." 9 Yet, to tailor all determinations

When the task of reallocating social roles involves shifting decisional authority and socioeconomic opportunity to long-silenced groups who have suddenly found a voice, it may make little difference whether the source of injustice is identified with the very act of the group's classification as a group or with a history of discrimination against the group so classified. For group identity, however involuntary and initially imposed from without, may in such instances become at once a source of solidarity, a symbol of oppression, a vehicle for claims in favor of benign quotas or reverse discrimination, and a basis for bargaining with the established order. It would be a mistake, however, to extrapolate this prudential lesson too directly from the experience of blacks or women, for example, to that of children-and particularly that of very young children. For in large part, their peculiar plight is that, by the nature of the case, they cannot make their political weight felt as a group-a circumstance perhaps relevant to the propriety of judicial intervention in their behalf and surely crucial to an understanding of how their rights will ultimately have to be vindicated. If children are to acquire the roles that are their due in a social order that resists generational as well as governmental domination, it will not be simply by lobbying or pressing their claims as a disadvantaged though emerging class, but by dissolving in addition the opaque wall of anesthetizing words that surrounds their existence and at times prevents adults from seeing themselves, both past and future, in the young persons whom they continue to dominate. In the end, to be sure, all instances of emancipation may come to much the same thing. The oppressor begins to see something of himself in the oppressed and is brought to recognize that it is finally himself he liberates when he lifts the yoke. But if this is true of other victims, it is even more dramatically true of children. No adult, having once been a child, can with real conviction draw the line between "us" and "them"- the line that makes it at least plausible in other contexts to treat "them" as a special minority needing protection from politics. Cf. Ely, The Wages of Crying Wolf: A Comment on Roe v. Wade, 82 YALE L.J. 920,933 n.85 (1973). I suspect that the adult is rare indeed who could fail completely to recognize that, by freeing the child in his midst, he may yet free the child in his soul.

9. See Cleveland Bd. of Educ. v. LaFleur, 414 U.S. 632 (1974) (invalidating as violative of due process a set of administrative regulations that compelled public school teachers to take leaves of absence in the fifth or sixth months of pregnancy and forbade them from returning to the classroom within three months after giving birth); United States Dep't of Agriculcure v. Murry, 413 U.S. 508 (1973) (invalidating as violative of due process a federal statutory provision that denied participation in the food-stamp program to any household containing an individual over the age of eighteen years who had been claimed as a tax dependent for the previous year by an individual not himself belonging to a household eligible for food stamps); Vlandis v. Kline, 412 U.S. 441 (1973) (invalidating as violative of due process a state statute that classified individuals as permanent nonresidents-and hence made them in- 
to the individual case, as the dissenters in those decisions powerfully argued, ${ }^{10}$ would be to encourage arbitrary choices, choices that depart from the goal of treating similar cases similarly, and choices that could well conceal substantively impermissible grounds of decision. ${ }^{11}$

\section{A First Common Thread: Rights}

This much, at least, the three puzzles have in common: all seem easiest to solve when the issue clearly involves the exercise of a right we have come to regard as constitutionally "fundamental," such as the right to bodily liberty or the right to be heard in one's own defense. Childhood need not be destroyed, dissolved, or ignored in order to recognize that when such a right is at stake, the general fact of youth alone cannot automatically justify the right's abridgement. Children need not be recognized as a despised minority for all purposes in order to suspect the lawmaker whose only excuse for a deprivation that would be intolerable as to adults is that "only children" are affected. And conclusive presumptions need not be abandoned wholesale in order to concede that readily unprovable generalizations about children-like all other measures for which "less restrictive

eligible for reduced tuition at state universities-solely on the basis that their legal address was outside the state at the time of their application to the university or, in the case of unmarried students, at any time in the twelve months prior to application); Stanley v. Illinois, 405 U.S. 645 (1972) (invalidating under a combined due process and equal protection analysis a statutory provision that automatically deprived unwed fathers of the custody of their illegitimate children upon the mother's death without allowing the fathers to establish their fitness as parents); Bell v. Burson, 402 U.S. 535 (1971) (invalidating as violative of due process a statutory provision that authorized suspending the license of any driver who is involved in an accident and who will not post security in the amount of the damage alleged to have resulted, without allowing the driver to present evidence of ultimate nonliability to prevent suspension). See also Reed v. Reed, 404 U.S. 71, 76-77 (1971) (invalidating under equal protection analysis a mandatory statutory preference for male over female administrators "merely to accomplish the elimination of hearings on the merits... [and to avoid] intrafamily controversy").

10. See the dissent of Justice Rehnquist, joined by Chief Justice Burger, in LaFleur:

My Brother STEWART [here] enlists the Court in another quixotic engagement in his apparently unending war on irrebuttable presumptions. . . . Hundreds of years ago in England, before Parliament came to be thought of as a body having general law-making power, controversies were determined on an individualized basis without benefit of any general law. Most students of government consider the shift from this sort of determination, made on an ad hoc basis by the king's representative, to a relatively uniform body of rules enacted by a body exercising legislative authority, to have been a significant step forward in the achievement of a civilized political society. It seems to me a little late in the day for this Court to weigh in against such an established consensus.

Cleveland Bd. of Educ. v. LaFleur, 414 U.S. 632, 657-58 (1974).

11. For a masterful synthesis of the arguments underlying decision in accord with the "rule of law," see McGautha v. California, 402 U.S. 183, 248-87 (1971) (Brennan, J., dissenting). 
alternatives" exist ${ }^{12}$-cannot suffice to justify what would, absent the fact of childhood, constitute an action beyond the power of the state. ${ }^{13}$

What emerges is a principle that at first may seem unexceptionable: Whenever it is agreed that government must provide a precise and potent justification for depriving a person of certain kinds of liberty or opportunity, highly generalized appeals to the characteristics of "the young" will not do. Insofar as the deprivation is to be justified by reference to immaturity and its supposed consequences, nothing less than demonstrable incapacity to make acceptable use of the opportunity in question should suffice. ${ }^{14}$

12. See, e.g., Shelton v. Tucker, 364 U.S. 479 (1960).

13. When the arena of controversy is located within the family itself and when the child or someone acting on his or her behalf seeks the aid of government against a parent in asserting a constitutional right, the issue obviously becomes more complex, since it now presents a difficult problem of allocating roles as between the family and the state. But it remains true that a ruling against the child in a case involving an otherwise "fundamental right" should not turn on the circumstance of childhood itself. If governmental action on the child's behalf would seriously disrupt the on-going internal processes of a basically harmonious family unit, one may well conclude that government should not intervene. In such a case, however, it is not the fact of childhood but the overriding values of family autonomy and integrity that would be thought to justify governmental abstention, just as they might justify such abstention when the party seeking the state's help is an adult. See note 85 infra. One doctrinal counterpart of this proposition may be the principle that associational considerations help to establish the boundaries of the "state action" concept in the first instance. See Henkin, Shelley v. Kraemer: Notes for a Revised Opinion, 110 U. PA. L. Rev. 473 (1972). Thus, routine cases of parental discipline in an essentially successful family whose continuation is mutually desired will properly be treated as raising no real constitutional issue even when the state extends various forms of incidental support to parental authority; in these cases, it may well be said, the state simply should not be deemed responsible for how such authority is exercised, with the result that constitutional constraints will not apply. But when a family is in disintegration or at the threshold of collapse-as when an adolescent persistently seeks complete emancipation and is willing, in return, to relieve his or her parents of reciprocal obligations-then it seems wrong to exonerate the state of responsibility for such coercive parental measures as it permits even by its inaction. Once a person is capable of survival away from home and insists, after sustained reflection, upon a complete break, to permit his or her parents to "hold on" arguably shares most of the characteristics of enslavement rather than those of voluntary association. Whether a parent in this situation should be entitled to withhold all further support unless the child returns or at least obeys certain parental commands-as was the assumption at least in the early nineteenth century, see, e.g., Angel v. McLellan, 16 Mass. 28, $8 \mathrm{Am}$. Dec. 126 (1819) (minor son who had fled the country could not look to father for support); $c f$. Roe v. Doe, 29 N.Y.2d 188, 272 N.E.2d 567, 324 N.Y.S.2d 71 (1971) (father of twenty-year-old college girl allowed to withdraw all support because she refused to live in dormitory)-raises distinct issues that will not be pursued here. What matters for present purposes is simply that the values of family association and integrity cannot automatically override the constitutional personhood of the child who persistently seeks full autonomy any more than they can completely submerge the Constitution's underlying allocations of decisional roles beyond the natural reach of the family's internal structure into spheres of interaction between children and persons outside the family unit. See note 14 infra.

14. That the best paternalistic intentions toward children cannot substitute for procedurally fair juvenile hearings was the basic message of In re Gault, 387 U.S. I (1967), the Supreme Court's initial entry into this general field. It was not until two years later that the Court had occasion to declare explicity that children "are 'persons' under our Constitution," Tinker v. Des Moines Independent Community School Dist., 393 U.S. 503, 511 (1969), a declaration that dramatized the Court's decision to void school board actions that had punished peaceful student protest of America's Vietnam involvement. In Tinker, the Court 


\title{
The Thread Unwound
}

\author{
But "demonstrable incapacity" may, in fact, ask for too much. In no \\ area of constitutional controversy has our legal system wholly repudiated \\ rules of thumb. Even in the exercise of those most central freedoms of
}

had stressed the existence of parental consent to the black armbands the children had worn to school, just as in Gault it had noted the identity of interest between parent and child. Two years later, the Michigan Court of Appeals went further, holding in Buckholz v. Leveille, 37 Mich. App. 166, 194 N.W.2d 427 (1971), that a child claiming the right to have long hair could bring suit against a school board over his parents' opposition; the Michigan court could see no sense in a policy that would deny "a teen-aged litigant access to our courts [to challenge an expulsion from school] simply because he happens to be a minor." Id. at 167 , 194 N.W.2d at 427. To the same effect as Buckholz, although in a dramatically different setting, is In re Smith, 16 Md. App. 209, 295 A.2d 238 (Ct. Spec. App. 1972) (statutory interpretation), holding that a parent cannot force an abortion upon an unmarried minor child. Both Buckholz and Smith, on their facts, protected minors only from adverse government action bearing on their dealings with third parties; both left open the possibility that subsequent intrafamily discipline directed at behavior the parents disapproved might not be judicially reviewed, or if reviewed, might not be invalidated. But the holdings in those cases nonetheless importantly recognized what must be described as jurisdictional limits on the reach of family authority over children's lives outside the home. Even when parental opposition to a child's choices beyond those limits is religiously based and when following the parents' wishes would not gravely endanger the child's life-perhaps the strongest imaginable case for leaving the decisional role with parents-the Pennsylvania Supreme Court, in In re Green, $448 \mathrm{~Pa}$. 338, 292 A.2d 387 (1972), insisted that the choice be left to the child, as it remanded for a hearing to ascertain whether or not the sixteen-year-old son of a Jehovah's Witness wished to accept, over his mother's religious objection, medical treatment for curvature of his spine; $c f$. In $r e$ Sampson, 65 Misc. 2d 658, 317 N.Y.S.2d 641 (Fam. Ct. 1970) (ordering blood transfusion on similar facts over parental objection without consulting fifteen-yearold child). See generally Skegg, Consent to Medical Procedures on Minors, 36 MoD. L. Rev. 370 (1973). In a similar vein, another district court, addressing a question left open by the Supreme Courts abortion decision, Roe v. Wade, 410 U.S. 113, 165 n.67 (1973), held in Coe v. Gerstein, 376 F. Supp. 695 (S.D. Fla. 1973), appeal dismissed for want of jurisdiction, 417 U.S. 279 (1974), that a state cannot constitutionally require spousal or parental consent as a precondition of allowing an abortion of a nonviable fetus to be performed on a pregnant woman under eighteen years of age. As the court put it in Gerstein, "a pregnant woman under 18 years of age cannot, under the law, be distinguished from one over 18 years of age in reference to fundamental, personal, constitutional rights," despite the fact that "the family unit is [ordinarily] a self-governing entity and that the traditional and primary obligation for the custody, care, control, and nurture of minor children resides in their parents." 376 F. Supp. at 695 , 698. In accord with Gerstein, but relying only on interpretation of a statute, is Ballard v. Anderson, 4 Cal. 3d 873, 484 P.2d 1345, 95 Cal. Rptr. 1 (1971) (en banc).

Lest it be supposed, however, that parental consent has become altogether irrelevant in the modern cases, it should be stressed that even as to children in public school-and hence in some sense temporarily committed to the state's care-informed consent by parent and child alike has been held a constitutional prerequisite of procedures not affirmatively sought by the child, but "offered" to children as a group for reasons of supposed public benefit. Thus, in Merriken v. Cressman, 364 F. Supp. 913 (E.D. Pa. 1973), a federal district court held that a proposed public school program of tests that would have asked pupils to answer highly personal questions in order to help school authorities identify potential drug abusers among eighth-grade students would violate the constitutional rights to privacy of the students involved because the students and their parents were insufficiently informed of what the program entailed and how its results might be used. 
expression and association, we have assumed that persons are properly regulated by rules that might well prove imperfect from the perspective of the individual case. "No shouting fire (falsely) in a crowded theater" states a rule of thumb that will not fit every case; some such shouts will cause no harm. Yet, such a rule's validity could not seriously be questioned simply because, in some of its applications, it would be guilty of overkill. Not even in its heyday did the doctrine of first amendment overbreadth go so far. ${ }^{15}$

If this is so, then why not a bit of overkill with respect to kids? The opportunity to vote is central to our constitutional scheme; deprivations of that opportunity must be strictly scrutinized by the judiciary and must be invalidated unless precisely and powerfully justified. ${ }^{16}$ But does it follow that every infant must be accommodated at the polls unless and until the state comes forward with particularized proof of each specific infant's incapacity? To put the proposition, it seems, is to answer it. It may be that overly generalized appeals to "youth" cannot suffice when otherwise fundamental rights are at stake; but fully particularized findings about each affected individual cannot be required either, at least as a matter of course. ${ }^{17}$

15. See generally Note, The First Amendment Ojerbreadth Doctrine, 83 HaRv. L. Rev. 844 (1970): $c f$. Broadrick v. Oklahoma, 413 U.S. 601 (1973).

16. See, e.g., Kramer v. Union Free School Dist. No. 15, 395 U.S. 621 (1969); Harper v. Virginia Bd. of Elections, 383 U.S. 663 (1966). But cf. Salyer Land Co. v. Tulare Lake Basin Water Storage Dist., 410 U.S. 719 (1973); Mahan v. Howell, 410 U.S. 315 (1973).

17. The notion is as old as the recognition that mechanical rules, despite their imperfection, may be preferable to logically sounder but harder-to-apply subjective standards. I am indebted to my colleague, Duncan Kennedy, for calling attention to an illustrative passage from R. von lhering, Der Geist Das Reomischen Recht (The Spirit of Roman Law) (2d ed. 1883). Kennedy's translation (of the French translation) of 1 id. at 51-56, is as follows:

[T]ake the example of civil and political personal capacity (majority and electoral right). Suppose that a legislator wishes to regulate this legally and he comes forth with this idea: he who has the judgment and stability of character required to regulate his own affairs will be of full age; he who possesses the capacity and wish to contribute to the good of the state will be an eligible elector. As just as this idea is, it would be absurd to institute it as a law in abstract form, as one would suffer infinite pains to determine in each case the existence of these conditions. This legislator would create an inexhaustible source of controversies and would give free reign to the arbitrariness of the judge. The most irreproachable application of his law would not be safe from the objection of partiality, which the legislator would have provoked by his own action. How can the legislator avoid this stumbling-block? Instead of these conditions, he will fix others, which have with the first a certain correlation, although not a one-to-one correspondence, but which have the advantage over them of being more easily and surely recognized in a concrete manner; for example, the attainment of 25 years of age for majority, the possession of a certain wealth, the practice of certain professions, etc., for the right of elector. This deviation from the original legislative idea, this abandonment of a more exact hypothesis in an abstract form, in favor of a less exact and less adequate one more easily recognized in practice, is required by one of the law's own purposes-by the desirability of facility and certainty in its functioning. It is possible here and there in applying this law that mistakes will occur, that majority or electoral rights will be granted or refused in particular cases where they wouldn't be under the abstract terms; yet this concrete 
So long as the "fit" between an appropriate purpose and the circumscribing of a right is sufficiently close in light of the values affected, ${ }^{18}$ there is no basis in the general run of cases for demanding anything more.

\section{A Second Thread: Rules}

The "general run of cases," however, may conceal quite a different sort of thread. To discern it requires a shift of focus-away from the category of rights and toward the problem of rules. There are situations in which the demand for "decision according to rules" itself assumes constitutional magnitude. A long line of familiar Supreme Court holdings denies unruled discretion to licensing officials in areas tinged with first amendment values ${ }^{\mathbf{1 9}}$ reformists urge that fundamental fairness to children demands a standard more definite than one looking vaguely to their "best interests" in custody disputes; ${ }^{20}$ explicit constitutional prohibitions force legislatures to outlaw conduct by enacting generally applicable rules rather than by designating who shall be punished; ${ }^{21}$ and the wholly discretionary-and "hence" arbitrary-imposition of the death penalty is held unconstitutional by the Supreme Court as a "cruel and unusual punishment."22

I put the "hence" in quotes for a reason; we do not always equate individualized judgments, largely unbound by rules, with arbitrariness, inequality, or the hidden use of forbidden criteria; the lives of successful families and of other intimate communities belie any easy equation between the informal and the suspect. Indeed, it is arguable that the demand for judgments of precisely that sort-individualized, informal judgments-no less than the demand for judgments in accord with determinate rules, may itself be constitutionally propelled in certain circumstances. (The trick, you will have guessed, is to say what those circumstances might be and why.)

Notice, first of all, how radical a claim this really is. No amount of "equal

mode of procedure is nonetheless preferable, in view of the necessities of life.

This point of view, in law, is the only determinant.

Much of this article will be devoted to the argument that the "point of view" defended by Ihering, however important and valid, is not "the only determinant." $C f$. Aristotle's defense of equitable "rectification of law where law is defective because of its generality." Aristotle, Nichomachean Ethics bk. 5 (H. Rackham transl.), in C. Morris, The Great Legal Philosophers 25 (1959).

18. See, e.g., United States Dep't of Agriculture v. Murry, 413 U.S. 508, 519 (1973)

(Marshall, J., concurring); Vlandis v. Kline, 412 U.S. 441, 459 (1973) (White, J., concurring); Dandridge v. Williams, 397 U.S. 471, $519-21$ (1970) (Marshall, J., dissenting).

19. See e.g., Saia v. New York, 334 U.S. 558 (1948); Lovell v. City of Griffin, 303 U.S. 444 (1938); $c f$. Kovacs v. Cooper, 336 U.S. 77 (1949).

20. See, e.g., Mnookin, Foster Care-In Whose Best Interest?, 43 Harv. Ed. Rev. 599 (1973).

21. See United States v. Brown, 381 U.S. 437 (1965); Note, The Bounds of Legislative Specification: A Suggested Approach to the Bill of Attainder Clause, 72 YALE L. J. 330 (1962).

22. See Furman v. Georgia, 408 U.S. 238 (1972) 
protection" analysis can adequately sustain it, ${ }^{23}$ since its thrust is to complain not of a mismatch between classifications and purposes, between rules and ends; its complaint, if taken at face value, is with the very use of binding and determinate preexisting rules. The remedy, given such a complaint, cannot be just a better fitting (though equally determinate) rule; it must instead be an individualized hearing leading to an essentially ad hoc determination, ${ }^{24}$ in apparent contrast with the traditional demand that delegations of power be confined by clear guides to decision, serving both the interest in regularity and the interest in accountability. ${ }^{25}$ But then that's it, you say: We are talking simply of "procedural due process," with its now quite conventional demand that governmental deprivations of a person's legally protected interests in life, liberty, or property must, absent exigent circumstances, be preceded by a hearing at which the affected individual has a meaningful opportunity to confront the responsible decisionmaker, to hear the decision-maker's reasons for the deprivation that is about to occur, and to contest both the applicability of those reasons to the facts of his particular case and the adequacy of those reasons in light of preexisting understandings generated by the state. ${ }^{26}$ What could be

23. See generally Developments in the Law-Equal Protection, 82 HARv. L. Rev. 1065 (1969).

24. A determination can, of course, be "ad hoc" without being wholly unguided by obligatory standards or principles; the crucial distinction for our purposes is that between relatively mechanical, objectively applicable rules (for example, "unmarried males shall not raise children") and plainly indeterminate principles and/or policies requiring inescapably subjective assessments of individual facts and circumstances in a full hearing (for example, "unfit persons shall not raise children"; or "foster parents should be assigned so as to maximize the well-being of children"). Cf. Dworkin, The Model of Rules, 35 U. CHr. L. Rev. 14, 22-40 (1967). It is true that, in two of its "irrebuttable presumption" decisions, the Supreme Court suggested that redrawing a categorical classification might be an acceptable alternative to granting a hearing under a less determinate standard. See Cleveland Bd. of Educ. v. LaFleur, 414 U.S. at 647 n.13 (indicating that a more limited, although still not universally accurate, presumption as to "some firm date during the last few weeks of pregnancy" might be allowable if supported by a "widespread medical consensus about the 'disabling' effect of pregnancy on a teacher's job performance during these latter days, or evidence showing that such firm cutoffs" were administratively necessary); Vlandis v. Kline, 412 U.S. at $452-53$ n.9. But the basic thrust of the decisions is to compel ad hoc determinations in the vast majority of the situations addressed by them, and the exception suggested by LaFleur arguably refers only to situations characterized by such widespread consensus as to make the distinction between determinate rules and indeterminate principles or policies virtually disappear.

In some contexts, a further distinction between "principles" (indeterminate standards to be observed because of their intrinsic worth) and "policies" (indeterminate standards to be observed because of their likely contribution to some further end) is worth making, see, e.g., Dworkin, supra at 23; certainly the ad hoc character of decision in accord with policies is clearest of all. But for the remainder of this article, reliance will be placed not on such a distinction, but simply on the distinction between principles or policies, on the one hand, and rules (determinate, "all-or-nothing" standards), on the other.

25. See A.L.A. Schechter Poultry Corp. v. United States, 295 U.S. 495 (1935); cf. McGautha v. California, 402 U.S. 183, 248 (1971) (Brennan, J., dissenting); Giaccio v. Pennsylvania, 382 U.S. 399 (1966). The contrast may be more apparent than real, since the degree of discretion permitted under Schechter, as currently construed, is not significantly narrower than that resulting from the "irrebuttable presumption" decisions.

26. See, e.g., Perry v. Sindermann, 408 U.S. 593 (1972) (nontenured teacher's state-gener- 
more antithetical to such a right to be heard, you ask, than to be burdened with an irrebuttable presumption-a rule refusing to hear evidence on some crucial fact?

Not so fast, one must reply. To be sure, if government concedes that a certain fact is crucial to your retention of a protected interest in liberty or property (or if government has made that fact crucial by rules previously promulgated), then government's absolute refusal to hear your version of that fact denies you the hearing to which you are constitutionally entitled; and the same is true if government pretends that the fact is irrelevant while deliberately seeking to exploit a widespread assumption to the contrary. ${ }^{27}$ Some such "false labeling" notion, indeed, might partly account for several of the Supreme Court's decisions striking down irrebuttable presumptions. ${ }^{28}$ But it is simply question-begging in many cases to put the matter

ated expectation of contract renewal may have created a property interest sufficient to require a pretermination hearing); Board of Regents v. Roth, 408 U.S. 564 (1972) (no right to hearing absent justified expectation of renewal); Morrissey v. Brewer, 408 U.S. 471 (1972) (right to hearing before parole revocation); Goldberg v. Kelly, 397 U.S. 254 (1970) (right to hearing before welfare termination).

27. In Arnett v. Kennedy, 416 U.S. 134 (1974), for example, six members of the Supreme Court were prepared to hold that Congress, having created what looked like a property entitlement (by statutorily guaranteeing certain Civil Service employees that they could be discharged only for "cause"), was powerless to qualify its character by adding a caveat that the seeming entitlement could be withdraw'n without a hearing-perhaps because such a course seemed an unacceptable circumvention of political accountability. Alternatively, Arnett might be read as standing for (1) the proposition that practice and context can enlarge an entitlement beyond its statutory definition; (2) the thesis that judicial deference to legislative judgments of procedure is less appropriate than judicial deference to legislative judgments of substance; or (3) the proposition that even relationships of public employment, and not merely relationships of private contract, see Fuentes v. Shevin, 407 U.S. 67 (1972); cf. Ogden v. Saunders, 25 U.S. (12 Wheat) $213,344-57$ (1827) (Marshall, J., dissenting), have a constitutional core independent of the body of positive law in contemplation of which such contractual relationships are entered. But see Board of Regents v. Roth, 408 U.S. 564 (1972).

28. Although the account may well be a tenuous one, it might be that the Georgia licensesuspension statute struck down in Bell v. Burson, 402 U.S. 535 (1971), would never have been enacted if it had been generally understood that no finding of liability need occur prior to temporary loss of one's driver's license; that the residents of Connecticut would have opposed the tuition scheme that the Court invalidated in Vlandis v. Kline, 412 U.S. 441 (1973), had they understood that some individuals who were residents in the usual sense might nonetheless find themselves automatically precluded from enjoying the lower tuition fees set for other residents of the state; and (still less plausibly) that the food-stamp provisions held unconstitutional in United States Dep't of Agriculture v. Murry, 413 U.S. 508 (1973), would have been defeated in Congress had it been clear that they were not, in fact, designed to measure economic need. The decisions in Bell, Vlandis, and Murry might thus rest at least in part on the common theme of ensuring political accountability. See also Leary v. United States, 395 U.S. 6 (1969) (if Congress wishes to make mere possession of narcotics a crime, it must do so explicitly and cannot employ factually attenuated presumptions to circumvent that obligation). See Ashford \& Risinger. Presumptions, Assumptions, and Due Process in Criminal Cases: A Theoretical Overview, 79 YALE L.J. 165, $177-78$ (1969). Each of those three cases, however, is at least susceptible of other explanations-Bell, as involving a troublesome delegation of ordinarily public authority to the private party who, by naming the level of damages required as security of the driver, can assure the suspension of the latter's license; Vlandis, as involving an arguably impermissible burden on the student's right to engage in interstate travel; and Murry, as reflecting an imperfectly enforceable affirmative obligation on the part of government to 
that way. When a public agency deprives an unwed father of his child's custody, ${ }^{29}$ to state a case we shall consider several times, it may not be acting on a presumption or finding of "unfitness" in any ordinary sense; the state may deem "fitness," as such, irrelevant, choosing its rule for the explicit and irreducible purpose of implementing and expressing a substantive preference for families of a more traditional sort. ${ }^{30}$ In that event, one can hardly say that the father has been denied a hearing on any fact the state has made crucial to his case. The wrong-if a wrong, indeed, has been committeddoes not lie in a procedurally unfair method of ascertaining what is, in fact, the truth. ${ }^{31}$

At this juncture, two choices initially appear. The first is to deny the state the substantive power to pursue the policy it seems to have chosen; the second is to concede such power and, with it, the right to proceed without any hearing on fitness. To someone who is uncomfortable with the second alternative but not quite willing to embrace the first with all its heavy overtones of "substantive due process," 32 the situation is likely to seem an unwelcome one. What, then, has become of our claim that in some situations, constitutional arguments might push us to individualization and away from rules?

\section{IV}

\section{Two Further Twists: Time and Process}

What has occurred, I think, is that we have allowed old habits of thought to prevail too quickly. We have accepted an essentially static (as well as instru-

meet basic human needs. See Tribe, The Supreme Court, 1972 Term-Foreword: Toward a Model of Roles in the Due Process of Life and Law, 87 HARv. L. REv. 1, 8 n.41, 49 n.224 (1973) [hereinafter cited as Foreword: Toward a Model of Roles].

29. See Stanley v. Illinois, 405 U.S. 535 (1971).

30. Cf. Village of Belle Terre v. Boraas, 416 U.S. 1 (1974) (sustaining a zoning ordinance that sought to preserve "family values" by restricting land use to one-family dwellings, defining families to include only groups "related by blood, adoption, or marriage" and groups of not more than two unrelated persons). It is when such a tautological defense, see Foreword: Toward a Model of Roles 5-6, either is not advanced, see notes 53-54 infra and accompanying text, or could not constitutionally be advanced, that a regulation or statute couched in terms of a mechanical criterion (such as sex, marital status, or membership in a designated group) must be treated as embodying an empirical finding, without trial or hearing, about the identifiable class of persons who meet the criterion. In such cases, one can persuasively argue that the regulation or statute is a forbidden bill of attainder. $C f$. United States v. Brown, 381 U.S. 437 (1965). To advance such an analysis without regard to the availability of a constitutionally permissible tautological defense, see Note, 72 YALE L.J. 330 (1962), however, seems mistaken. For no further "finding" without trial occurs when the very fact singled out by the mechanical criterion is openly and permissibly made the law's target.

31. See Note, The Irrebuttable Presumption Doctrine in the Supreme Court, 87 HARv. L. Rev. $1534,1545-48$ (1974).

32. See, e.g., Ely, The Wages of Crying Wolf: A Comment on Roe v. Wade, 82 YALE L.J. 920, 937-49 (1973); Strong, The Economic Philosophy of Lochner: Emergency, Embrasure, and Emasculation, 15 ARIz. L. REv. 419, 455 (1973). 
mental) model of law and policy ${ }^{33}$ in which the state is deemed either to "have" a certain policy or not, and in which the policies a state "has" are then either "applied" or "not applied' in particular factual situations. In this model, the familiar substance-procedure dichotomy fits most comfortably. Given a policy that the state has, one can ask, substantively, whether the content of that policy comports with various constitutional limits on the ends government may pursue and the means it may employ; and given an attempted invocation of the policy to someone's disadvantage, one can ask, procedurally, whether the application of the policy has been sufficiently accurate as a means of implementing its purposes.

But consider for a moment a more dynamic and less instrumental picture of policy and its formation-a motion picture (1) in which we are as concerned with the development of policy over time as with a snapshot of policy at any given point, ${ }^{34}$ and (2) in which we are as interested in the process of decision itself as with the outcomes produced..$^{35}$ In some areas, once the likely process of policy-formation comes into historical focus, it will be arguable that-for a time, at least-government ought to have no policy at all, in the sense that it ought to leave the area entirely to private ordering and choice. ${ }^{36}$ More commonly, we will be unprepared to make a constitutional argument for such governmental abstention (in effect, for substantive due process invalidation) but may yet be prepared to advance a less drastic proposition: that the area in question is one where governmental policyformation andlor application are constitutionally required to take a certain form, to follow a process with certain features, or to display a particular sort of structure. ${ }^{\mathbf{3}}$

33. Cf. Tribe, Technology Assessment and the Fourth Discontinuity: The Limits of Instrumental Rationality, 46 S. CaL. L. Rev. 617, 618-19, 625-41, 650-60 (1973).

34. Cf. Tribe, Ways Not to Think About Plastic Trees: New Foundations for Environmental Law, 83 YALE L.J. 1315, 1338-46 (1974).

35. Cf. Tribe, Policy Science: Analysis or Ideology?, 2 Phil. \& Pub. Affairs 66, $79-83$ (1972).

36. For an illustrative argument to the effect that giving government the role of deciding whether or not to veto early abortions generates a process of impermissible church-state entanglement, see Foreword: Toward a Model of Roles 15-32, 50-52. Compare Justice Harlan's observation that "the continuing debate respecting birth control and abortion laws" typifies the very "risk of politicizing religion" and of creating "political fragmentation on sectarian lines" which the first amendment's separation of church and state was designed to avoid. Walz v. Tax Comm'n, 397 U.S. 664, 695 (1970) (separate opinion of Harlan, J.). Considerations of this sort-much more than objections to the actual content of particular governmental controls over abortion-at least make comprehensible the Supreme Court's holding in Roe v. Wade, 410 U.S. 113 (1973), that the decision whether or not to abort must be a private one prior to fetal viability.

37. The "role-allocation" model developed in Foreword: Toward a Model of Roles is, therefore, but a special case of a more general and more powerful concept: The Constitution constrains and shapes the choice among alternative processes of policy-formation and decision no less than it controls either the content of the specific policies formed or their accurate application to particular cases. Cf. United States Dep't of Agriculture v. Murry, 413 U.S. 508, 519 (1973) (Marshall, J., concurring) (hinting at the notion that "irrebuttable presumption" analysis involves constitutional scrutiny of the choice between rule-making and adjudication in specific contexts). See also sources cited in note 21 supra. 
Two relatively obvious examples should make the point. The Constitution says virtually nothing about what the substantive content of American fiscal policy ought to be; but it says plenty about how the process of arriving at such policy ought to be structured, assigning quite definite roles to the Executive Branch and to the Congress. ${ }^{38}$ And the Constitution says very little about what conduct the states should define as criminal; but it says a great deal about how the process of identifying and punishing criminals must be designed, and it often specifies procedural constraints whose importance goes far beyond their likely impact on the accuracy of trial results. ${ }^{39}$

A further illustration will serve to bring us closer to home, although along a somewhat surprising path. In Witherspoon $\%$. Illinois, ${ }^{40}$ the Supreme Court grappled with the problem of death-qualified juries-juries in capital cases from which all persons with any scruples about the death penalty (not merely those who would never vote for death, but all who would feel qualms at doing so) had been eliminated. The Court held that the infliction of death at the hands of such a jury would violate due process because any such jury was impermissibly "stacked" in favor of death. The thrust of Justice White's dissent was to ask: So what? ${ }^{41}$ What's wrong with a state policy that everyone who has done $X$ should die unless even the most bloodthirsty members of the community favor life imprisonment? Justice Stewart's reply for the Court is worthy of close attention: The state has not, in fact, openly articulated the sort of policy attributed to it by Justice White; ${ }^{42}$ and even if it had, the interposition of a jury representing a fair cross-section of community sentiment with respect to capital punishment is a vital step in assuring that the penal system keeps in touch with evolving standards of civilized treatment. Given contemporary shifts in feeling about the death penalty ${ }^{43}$ and a legislative process unable (or at least highly unlikely) to respond pliably to such shifts, ${ }^{44}$

38. See, e.g., Kendall v. United States ex rel. Stokes, 37 U.S. (12 Pet.) 524 (1838) (Postmaster General must spend the amount Congress dictates): State Highway Comm'n v. Volpe, 479 F.2d 1099 (8th Cir. 1973) (invalidating an attempted impoundment of appropriated funds).

39. See, e.g., C. Fried, An Anatomy of Values 125-32 (1970); E. Goffman, Interaction Ritual 10-11, 19, 54 (1967): Tribe, Trial by Mathematics: Precision and Ritual in the Legal Process, 84 Harv. L. Rev. 1329, 1391-93 (1971).

40. 391 U.S. $510(1968)$.

41. Id. at $540-42$.

42. Id. at 519 n. 15 .

43. See id. at 520 n.16 (citing polls to the effect that "in 1966, approximately $42 \%$ of the American public favored capital punishment for convicted murderers, while 47\% opposed it and $11 \%$ were undecided," whereas "[i]n 1960, the comparable figures [had been] $51 \%$ in favor, $36 \%$ opposed, and $13 \%$ undecided").

44. Although the Witherspoon Court did not address this issue, it seems hard to deny that convicted murderers make a singularly ineffectual legislative constituency; however widely or intensely humane opinion may condemn the death penalty as cruelly excessive, and however many jurors may be unable to participate personally in a defendant's execution, it remains likely that more votes will be lost than won by the platform of abolition, particularly if the death penalty is in fact carried out too infrequently or discriminatorily to generate sustained political pressure for its repeal. $C f$. notes 54 and 75 infra. 
"one of the most important functions any jury can perform in [selecting a punishment] is to maintain a link between contemporary community values and the penal system-a link without which the determination of punishment could hardly reflect the evolving standards of decency that mark the progress of a maturing society.'"45 Because the Court's concluding quotation is from a decision construing the eighth amendment's "cruel and unusual punishments" clause, ${ }^{46}$ Witherspoon seems most comprehensible as a simultaneous expression and prophylactic enforcement of the eighth amendment-the fashioning of a constitutionally-mandated structure that can (1) reflect the sense that executing persons in situations where communally shared beliefs can no longer be said to warrant the death penalty is morally unacceptable per se, while (2) minimizing the risk that an anachronistic punishment will persist in a legislatively rigid environment. ${ }^{47}$ Given the unavailability of any widely acceptable substantive criteria for judicially determining which punishments are constitutionally excessive at any particular time, Witherspoon's required confrontation between community conscience and the individual accused makes good sense.

As soon as one focuses through Witherspoon's lens on the problem of changing norms in particular, and once one considers the many obstacles that prevent law and policy from remaining abreast of such change, one discovers judicial devices for such "time-binding" at every turn. One sees them, typically, only in disguise; it is standard dogma, after all, that "[t]he Constitution does not require legislatures to reflect sociological insight, or shifting social standards, any more than it requires them to keep abreast of the latest scientific standards." 48 So one must not expect doctrine to wear its "updating" function on its sleeve. But one should expect to find traces of that function in many quarters. Two illustrations will make the point.

The first is the less typical; I note it primarily to suggest how pervasive, even if unintended or concealed, devices of this sort seem to be. In Roe $v$. Wade, ${ }^{49}$ the Supreme Court made fetal viability the point beyond which a

45. Id. at 519 n.15.

46. Trop v. Dulles, 356 U.S. 86, 101 (1958) (opinion of Chief Justice Warren, joined by Justices Black, Douglas, and Whittaker).

47. Note that Witherspoon's second justification, in this account, is an instrumental one (the decision serves indirectly to reduce the probability that government will continue to inflict punishments that have become constitutionally anachronistic as applied to particular facts-in a sense independent of disintegrating communal support, even if detectable in no other way); whereas its first justification is to be accepted (or rejected) purely in terms of its intrinsic worth (the decision defines as constitutionally unacceptable any punishment no longer supportable by communally shared beliefs).

48. Goesaert v. Cleary, 335 U.S. 464, 466 (1948) (Frankfurter, J., upholding a Michigan statute that prohibited a woman from being a bartender unless she were the wife or daughter of the bar's owner). But cf. Wellington, Common Law Rules and Constitutional Double Standards: Some Notes on Adjudication, 83 YALE L.J. 221 (1973).

49. 410 U.S. $113(1973)$. 
state's power to protect a fetus overrides a woman's right to control her own reproductive processes. Why viability? I have elsewhere suggested one analysis that might justify drawing the line there, ${ }^{50}$ but the interesting fact about viability for present purposes is its variable character; as medical technology advances, the fetus is likely to become viable-capable of survival outside the womb-at points ever closer to conception itself. ${ }^{51}$ That the impact of Roe $\%$ Wade as a limit on state power to protect the unborn may hence be expected to diminish with time seemed to me, in an earlier article, entirely appropriate in a constitutional framework that must necessarily evolve through history. ${ }^{52}$ But more can be said. For the overriding difficulty with the Court's abortion decision as a moral matter must surely be its subordination of one functional "minority" (the unborn) to another (women). If this is so-and if Roe must be seen as purchasing the partial liberation of one group with the enslavement (or worse) of another-at least it must be said that the choice of viability as the cut-off may make the sacrifice temporary by adopting a potentially "self-destructing" line; the choice of viability leaves open the path to greater protection of the unborn if and when the commitment of public resources to their well-being, as evidenced in part by an acceleration of the time of viability, makes that a more plausible and widely shared ideal.

The second illustration of "time-binding"-more to the point, if less dramatic, than the first-is the emergence in the Supreme Court's jurisprudence of an "articulated rationale" approach to judicial review-an approach in which a challenged government action will not be sustained as advancing an imagined purpose, however legitimate, that has not actually been argued to the Court. ${ }^{53}$ Although I have elsewhere expressed misgivings about the propriety of such a stance, ${ }^{54}$ it has at least this to commend it: By permitting

50. Foreword: Toward a Model of Roles 27-28, 32-33 n. 144.

51. See id. at 3 n. 18 .

52. See id. at 3 n.13, 27 n.118.

53. See, e.g., Cleveland Bd. of Educ. v. LaFleur, 414 U.S. 632, 641 n.9, 651 (1974); Gunther, The Supreme Court, 1971 Term-Foreword: In Search of Evolving Doctrine on a Changing Court: A Model for a Newer Equal Protection, 86 HARv. L. REv. 1 (1972). Professor Gunther's formulation of the approach is somewhat ambiguous; he suggests that the only purposes to be considered are those expressed-or at least entertained-by the enacting legislature, see $i d$. at $28,44-46$, but at some point he also suggests that the only purposes to be considered are those argued by the state's representatives in the lawsuit. See id. at 35, 47. The first of these formulations would have to be defended, if at all, in terms of encouraging legislative accountability and improving the quality of public debate preceding the enactment of legislation, of. note 28 supra; it is the second formulation alone that is of concern in what follows. $\mathbf{5 4}$.

A mismatch between means and ends, when the only ends examined are those argued in a law's defense by an executive officer, may indicate no more than that the officer did not advance the right ends in the law's defense. That his oversight or deliberate choice should be allowed thereby to frustrate the past efforts of his jurisdiction's legislature seems strange. Nor can I imagine any satisfactory way of forcing 
the Court to disregard objectives that governmental officials are themselves unwilling to press in a law's defense, the approach operates much like a doctrine of desuetude, working to deprive legislation of supporting arguments -and hence increasing the likelihood of its invalidation on the seemingly "neutral" ground of arbitrariness or irrationality-precisely as legislation loses touch with evolving values and conceptions, but before a new consensus sufficient to repeal the law has yet emerged.

Moreover, to invalidate as arbitrary a law that seems irrational when viewed exclusively in terms of the reasons currently offered in its defense may, in fact, reflect the same basic ideal of dialogue that underlies the accepted doctrine that wholly arbitrary laws-laws serving no imaginable purpose-offend due process. For that doctrine can be explained most readily as an expression of the requirement that laws, unlike naked commands, must be understandable to those they touch-that the person whose freedom is subjected to a particular control is entitled to a responsive answer from the sovereign (as a matter of what I would call "structural" due process) when he asks why the control has been imposed, just as he is entitled to be told (as a matter of procedural due process) why the control applies to him. If no comprehensible answer is forthcoming, it matters little from this dialogue-centered perspective whether the reason is that the law serves no imaginable purpose (the usually accepted "neutral" ground for substantive due process invalidation) or that it serves no purpose its defenders are willing to articulate (the ground for invalidation under the "articulated rationale" approach to due process and equal protection cases). Indeed, sustaining a law on grounds that its challenger has had no real chance to refute arguably offends traditional notions of procedural fairness quite apart from the notion advanced here that the law's continuing substantive validity may depend on the terms in which it is defended over time.

To be sure, at least one serious cost may be associated with the approach under discussion. It may invite judicial invalidation exactly when a more passive stance by the courts might have energized the political processafter a brief period of unsatisfying dialogue, and hence a form of injustice

the executive to defend a law in terms of the legislature's own, often conflicting, goals, whether hidden or publicly expressed.

Foreword: Toward a Model of Roles 6 n.28. Against this view must be set the argument outlined above and the recognition that a state's executive is often in a position to "frustrate the past efforts of his . . . legislature" by choosing not to enforce, or not to defend vigorously, the law's those efforts have produced. It may be that extreme cases of such nullification so distort the normal channels of opposition to a law as to render it void for "desuetude," see A. BickEL, The Least Dangerous Branch 152 (1962), but unless prosecutorial discretion not to enforce is generally to be denounced as inconsistent with a prosecutor's duty faithfully to execute the laws, a doctrine that simply adds one more way for the executive to abandon an unpopular law cannot be regarded as all that "strange." On balance, therefore, I am now inclined to regard my prior misgivings about the "articulated rationale" approach as quite ill-founded. 
-into some updating action of its own. Much as one could for this very reason advocate the passive virtues of judicial abstention when long-continued failure to enforce a law hints at the breakdown of an old consensus and the possible emergence of a new, ${ }^{55}$ one might well conclude that the "articulated rationale" device risks bringing the judiciary prematurely into areas that, if left alone, would soon resolve themselves politically-and with more constructive consequences than would be likely to attend judicial burial of statutes almost, but not quite, dead. ${ }^{56}$

More will be said of this objection later. But first we must return for a moment to the custody dispute involving our unwed father. When we last encountered him, ${ }^{57}$ he was in the awkward position of having either to accept the loss of his child or to challenge the state's power deliberately to pursue a policy of discouraging families structured like his own. The "articulated rationale" advocate might come to the father's rescue by suggesting that, unless the state's current representatives are willing to come out publicly against motherless families as such, the custody court need not consider that policy at all and can thus strike down the unwed-father rule as irrational because too poorly matched to any other imaginable objective in light of the fundamental character of the interests at stake. The rescue might well be short-lived, however, since state officials might in fact have few qualms about offering the hypothesized defense. And in any event someone would surely remind us that any victory the father might obtain in court through the proposed strategy would come at the price of an arguably needless expenditure of judicial resources, adding that such a victory could well provoke reformulations of the custody rules in directions that might not be at all in the father's interest.

Suppose, in particular, that our hypothetical father is confronted by a custody rule whose defenders, unlike those in the actual case of Stanley $v$. Illinois, ${ }^{58}$ openly proclaim the state's hostility to untraditional family arrangements. The rule depriving unwed fathers of custody, it is now plain, fits its articulated rationale like a glove. Must we be able to show that the rationale is itself substantively forbidden if the father is to prevail? (True, we have been here before; but we are now better prepared to suggest an answer than we were the last time around.) The answer, I think, is no. We can instead argue, in the same spirit as Witherspoon ${ }^{59}$ and along lines parallel to (but

55. $C f$. A. Bickel, The Least Dangerous Branch 143-56 (1962) (advocating abstention in the sense of not deciding the substantive issues posed by the law, but with the implication that its continued nonenforcement precludes its sudden reinvocation at the prosecutor's discretion)

56. This objection is, of course, distinct from the one quoted in note 54 supra and there rejected.

57. See text at p. 18 supra.

58. 405 U.S. 645 (1972). See note 9 supra.

59. Witherspoon v. Illinois, 391 U.S. 510 (1968). 
obviously going beyond) those of the "articulated rationale" approach, that this is an area in which the need to reflect rapidly changing norms affecting interests widely agreed to be fundamental compels a more individualized determination, one not bound by any preexisting rule of thumb within the zone of moral change. ${ }^{60}$ If one were to accept such an argument, then a rule absolutely requiring the custodyseeking father to have no prior child-beating convictions, for example, would be permissible (so long as not otherwise unconstitutional) because it is outside the zone of shifting norms with respect to sex roles and parenting; but a rule absolutely requiring a woman in the house as a precondition of custody would be impermissible (even if otherwise constitutional) because it is within that zone. What would be urged by the argument suggested here is not, of course, a decision adversely affecting fundamental rights or entitlements without giving any reasons at all; procedural due process would surely preclude any departure so total from the rule of law. What would be urged instead is that the decision-maker be under an obligation to resolve the dispute on its own terms, acting as appears just in the circumstances, but responsible for ultimately articulating some coherent explanation for the decision reached. ${ }^{61}$ Seeming to serve at once as rule-maker and rule-applier (but in reality serving as neither), the person responsible for decision would thereby enter into a dialogue about what rules, if any, should ultimately replace those of the earlier regime. Perhaps the day would come, spurred in part by a large number of such individualized decisions, when a new moral consensus would have crystallized in these matters. At such a time, the dangers of arbitrariness, of inequality, and of forbidden but invisible criteriadangers implicit in all essentially ad hoc decisions-might be expected once again to appear dominant, and the situation might then be ripe for a due process decision ( 1 ) requiring the legislative reimposition of binding and determi-

60. Any such argument would obviously be far more difficult to sustain as to rules of thumb affecting only those interests not yet agreed to have any significant constitutional dimension, or at least clear status as statutory entitlements. Sustaining the argument even as to constitutionally "fundamental" interests-such as those of expression, association, and sexual privacy-would, in itself, represent a shift from conventional doctrine. As seen earlier in Part II, individualized determinations-as opposed to well-fitting rules of thumb-have not generally been required simply because basic liberties have been at stake. The italicized principle would demand individualization when basic liberties seem threatened-but only in the presence of rapidly changing norms. Sketching a defense of that principle is part of what the remainder of this article seeks to do.

61. If such a decisional role is to make any sense, appellate review of its exercise must be confined to search for gross abuses under a standard of minimum rationality, rather like review of a jury's verdict in a civil case or an equity court's shaping of a fair remedy. It must be noted that the sort of individualized decision here described, despite its kinship with the "articulated rationale" approach, cannot be defended in the rather traditional terms suggested at pp. 22-23 supra. When the unwed father in the case we have hypothesized asks "why," he is offered a reason that fits the state's action perfectly: "Because we dislike motherless families; they seem to us bad in themselves." One might deem such a reason insufficient because too controversial; but, short of such substantive condemnation, one could demand no more in a conventional analysis. 
nate guides to decision, ${ }^{62}$ and (2) demanding, as a matter of equal protection, the appropriate "fit" of those guides to the ends that have emerged. But the aims of equality and regularity presuppose substantial agreement about the way in which cases are to be identified as "similar" or "dissimilar"; such agreement in turn presupposes some consensus about what substantive criteria should govern. So long as that consensus has not (yet) evolved, the hope implicit in the solution here described is likely to be that the individual decision-maker, confronting each case in all its particularity and constrained only by indeterminate standards, ${ }^{63}$ would be more open to evolving norms and expectations than any codification could be, and that the resulting gain in moral sensitivity would justify the attendant risks of arbitrary or capricious judgment.

Such a dissolution of determinate rules and labels always entails potential arbitrariness. But the risk is rarely avoidable. ${ }^{64}$ To emancipate any externally defined group in a society, one must always break the conceptual bonds that create its illusory coherence. Unlike a self-defining community of life, a category whose members do not to some extent choose themselves imprisons in the iron cage of language all those trapped-on both sidesbehind its bars. It has been so of "blacks" and "women"; it is so of "children."

Whether the discretionary decisions made in the period of such dissolution (if the argument sketched above were accepted) would, in fact, fit evolving moral conceptions more closely is in part an empirical and instrumental question as to which no significant light can be shed here. But it is also a question of process valued for its own sake-of individual human

62. Cf. Furman v. Georgia, 408 U.S. 238 (1972) (invalidating discretionary imposition of capital punishment). The many statutory and judicial attempts to respond to Furman by purportedly making death a mandatory punishment in specified cases seem exceedingly unlikely to succeed. For no society that prizes individualized treatment as well as the rule of law and values life as does ours can ever agree to extinguish it in any rigidly defined category of cases without delegating substantial discretion within that category to public agents-whether prosecutors, jurors, judges, or governors. See Note, Discretion and the Constitutionality of the New Death Penalty Statutes, 87 Harv. L. Rev. 1690 (1974).

63. See note 24 supra. Cf. Tribe, supra note 39 , at $1390-91$, discussing "the wisdom of being somewhat fuzzy and open-ended in one's statement of at least some kinds of standards ... that are designed to guide others over time . . . and leave one free to move in many different directions as one's understanding grows and as one's needs evolve." See also Freund, Social Justice and the Law, in Social Justice (R. Brandt ed. 1962) 93, 109-11; cf. D. Matza, DelinQUENCY AND DRIFT 111 (1964).

64. When the stakes are high enough and the issue sufficiently controversial, the lack of consensus may preclude governmental decision by determinate rules, while the risks of official arbitrariness affecting the most vital interests if ad hoc governmental decision is tolerated may mean that the relevant decisional power should, if possible, be taken from government altogether. Both the power to decide who should die and the power to decide who should be born may well be of that character-witness the constitutional disintegration of capital punishment and the constitutional privatization of contraception and abortion. 
confrontation as an intrinsically more fitting response than codification to the predicament of moral uncertainty and flux.

One might, indeed, regard such individualized, face-to-face confrontation of decision-maker and disputants as the only fitting response to serious human controversy in any community worthy of the name. Formal resolution of disputes, by detached reference to determinate rules that settle in advance the boundaries between persons and define the shape of their entitlements, might be thought inconsistent with any but an unacceptably atomistic, anomic, anticommunal conception of social life. ${ }^{65}$ No claim quite so radical, however, need be defended in order to make plausible a demand for individualized, informal justice in the special situation of widely perceized moral flux affecting rights (whether of property or of liberty) widely agreed to be fundamental, as in the case of dissolving moral consensus about the precise circumstances in which a person should be deprived of the right to raise his child. In any such situation, the generally recognized involvement of agreed-upon "fundamental rights"-here, rights of parenthood-reflects the existence of an underlying set of widely shared ralues, values whose objectification as protected entitlements and binding rules is consistent (as consistent, that is, as entitlements and rules can ever be) with the fraternal ideals of community. ${ }^{6}{ }^{6}$ It follows that the traditional due process demand for a hearing-and for governmental justification by the articulation of reasons rationally related to legitimate purposes-before such rights are adversely affected by government generates as little tension with the communal ideal as rules of law ever can. ${ }^{67} \mathrm{At}$

65. See generally Kennedy, Legal Formality, 2 J. Legal Studies 351 (1973).

66. To allege inconsistency at this level would be to challenge the ability of constitutionalism and community to coexist at all-a challenge I can appreciate but am unprepared to make or to accept.

67. My colleague Frank Michelman has argued in a provocative and illuminating essay soon to be published in NOMOS that there is a potential disharmony between the procedures that the Supreme Court has held "due process of law" to require (procedures fully understandable only on a fraternal conception of justice-one concerned with more than minimizing the risk that people will wrongly lose what is "theirs") and the Court's insistence that legally recognized "entitlements" be at stake before any "due process" requirement is triggered at all-an insistence fully consistent. Michelman argues, only with a formal and antifraternal conception. But the disharmony would at least be minimized if one were to view the Courts insistence on entitlements as reflecting an underlying sense that it is only with respect to "entitlements" in their broad sense-that is, only with respect to communally agreed-upon rights-that the very fact of conflict-resolution by judicially-compelled resort to hearings (or at least by resort to hearings anything like those traditionally conceived to be compelled by due process) can avoid undermining the fraternal aims - the aims underlying a demand for explanation and participation rather than merely justification-that such hearings should in part be designed to further. On this view, the Supreme Court's reluctance to extend due process safeguards beyond the area of recognized entitlements (at least if "entitlement" is to be somewhat loosely construed, as Arnett v. Kennedy, 416 U.S. 134 (1974) suggests it is) would be understandable as a response to the belief that judicially-compelled hearings triggered by anything less than communally accepted claims of right are peculiarly likely, even if no formal relief is granted, to become instruments of domination rather than community. 
the same time, the intersection of these widely recognized rights with a context (such as that of unmarried sex) characterized by evident moral uncertainty and conspicuously changing norms would make categorical, rule-bound resolution of disputes in the intersecting area (such as disputes about parental opportunities and obligations in the absence of marriage) clash most dramatically with the ideals of community life and fraternal relations. For it is only the existence of communally shared values expressed as rights and rules $^{68}$ that can hope to reconcile the tension between formal and fraternal conceptions of justice. When substantive rules cease to represent faithful expressions of communally shared ideals, they come to enforce-and to be perceived as enforcing-the interests and ends of others, ${ }^{69}$ and thereby to destroy even the most temporary and tentative harmony between the rule of law and the spirit of community-a harmony one can hope to sustain only in the presence of shared values and ends.

Against this background, an analysis similar to that for unwed fathers might plausibly be urged with respect to pregnant school teachers, new mothers, and mandatory maternity lay-offs. Again, the rapid flux in our culture's mix and range of attitudes relevant to the working mother or the working mother-to-be and significantly affecting how she makes fundamental, constitutionally protected choices about childbearing can go far toward justifying the Supreme Court's insistence on individualization in that setting, ${ }^{70}$ in a decision that parallels the Court's earlier holding that unwed fathers cannot conclusively be presumed to be unfit and automatically denied custody. ${ }^{71}$

From a more institutional perspective, it is worth noting that in both instances-in Cleveland Board of Education v. LaFleur and Stanley v. Illinois -the Court's interventions operated to force bureaucracies entrenched

68. For a discussion of rights as embodying and expressing, rather than merely implementing, aspects of self and community, see Tribe, supra note 35 , at $87 \mathrm{n} .54,88-89$.

69. Cf. Kennedy, supra note 65 , at 378-91.

70. Cleveland Bd. of Educ. v. LaFleur, 414 U.S. 632 (1974). If public officials had purported to tell teachers directly whether or not to have children, rather than applying automatic employment disqualifications, we would have had the sort of case contemplated in note 64 supra, where the stakes would be so high that the governmental role would have to be terminated altogether. Cf. Roe v. Wade, 410 U.S. 113 (1973) (invalidating control of early abortions); Griswold v. Connecticut, 381 U.S. 479 (1965) (invalidating prohibition on contraception); Skinner v. Oklahoma ex rel. Williamson, 316 U.S. 535 (1942) (invalidating mandatory sterilization).

By referring in the text to "constitutionally protected choices about childbearing," I do not mean to beg the difficult question of how such choices came to be "constitutionally protected" in the first place. For purposes of the present argument, however, it should suffice to note that the "widely shared values" underlying the Griswold-Roe-LaFleur judgment that reproductive choices should be privately made (absent an extraordinary justification for collective intervention) include the values of church-state disentanglement, see note 36 supra; of informational privacy, see Foreword: Toward a Model of Roles $17 \mathrm{n} .83$; of associational integrity, see id. at 34-38, especially 36-67 n. 162; and of bodily autonomy, see $i d$. at 38-41.

71. Stanley v. Illinois, 405 U.S. 645 (1972). 
within their respective communities to abandon automatic and comfortable reliance upon formal criteria rooted in a morality that was no longer widely shared. School boards were required by LaFleur to depart from lay-off rules originating in Victorian attitudes toward women, sex, and schools; ${ }^{72}$ childcustody courts and agencies were compelled by Stanley to end their reliance on rules grounded in views once broadly held about the proper role of men and the needs of children. ${ }^{73}$ In both cases, the shared understandings and ideals of an earlier time had been frozen into formal bureaucratic rulesin one instance, statutory; in the other, administrative-despite the fact that those very understandings and ideals had become profoundly controversial in the society at large.

But, then, why not wait, the advocate of judicial restraint will ask, for a new moral consensus to emerge? And why not trust majoritarian political processes to respond to that consensus once it has formed? Two answers seem worth considering. The first is simply that, if one agrees that anything but personalized justice is in itself constitutionally unacceptable in settling disputes about rights agreed to be fundamental when such disputes arise in settings of widely perceived moral flux, then one cannot accept even the interim resolution of such disputes-pending a possible new consensus -by impersonal, preexisting rules. A second answer is that, whether one rejects or accepts the thesis that individualized determinations are required for their own sake in such settings, one cannot invariably rely upon politics

72. For Justice Powell, concurring in LaFleur, the "initial primacy" of the desire "to keep visibly pregnant teachers out of the sight of school children" cast "a shadow over [the] cases" before the Court. 414 U.S. at 653. Precisely what the shadow's doctrinal significance might be, however, was not revealed. For Justice Stewart, writing for the majority, the likely origins of the maternity-leave regulations merited only a jocular footnote about school board fears that students might believe their teacher had "swallowed a water melon." Id. at 641 n.9. For neither the majority nor Justice Powell did anything beyond the rationale argued to the Court count in the regulations' defense. And if one were to limit one's evaluation to the argued rationale, see note 54 supra, one might find quite convincing the straightforward argument that the regulations are void as wholly arbitrary-if not, indeed, counterproductive.

73. Chief Justice Burger, joined by Justice Blackmun, dissented in Stanley. Both thought that states were "fully justified in concluding," even in 1972, and even in a case where the mother had died, "that the biological role of the mother in carrying and nursing an infant creates stronger bonds between her and the child than the bonds resulting from the male's often casual encounter." 405 U.S. at 665 . The same two Justices, in an opinion written this time by Justice Blackmun, more recently opined that

times have not changed in the area of moral precepts. Fundamental concepts of right and wrong are the same now as they were under the Articles of the Earl of Essex (1642), or the British Articles of War of 1765, or the American Articles of War of $1775 \ldots$

Relativistic notions of right and wrong, or situation ethics, as some call it, have achieved in recent times a disturbingly high level of prominence in this country, both in the guise of law reform, and as a justification of conduct that persons would normally eschew as immoral and even illegal.

Parker v. Levy, 417 U.S. 733, 763, 765 (1974) (concurring in the opinion of the Court sustaining a provision of the military code over a claim of extreme vagueness). 
ever to replace the disintegrated moral view with a new consensus and then to supplant the intensely controversial rule with a generally acceptable one, thereby adequately protecting "fundamental rights." In this second connection, it is striking that, as I will try to show, the bureaucratic reality confronted by the Court in LaFleur and Stanley alike seemed calculated to prevent the formation of a new consensus that, translated into legislative or administrative action, could otherwise have obviated the need for judicial interference-at least on the view that individualized justice is required not in itself, but only as an instrument of legal evolution. ${ }^{74}$ To be more precise: Even if one generously treats the institutions affected by LaFleur and Stanley as potentially responsive to external pressures, one must at least notice--although the Court itself said nothing about the matter-that the institutions in question were so situated that they could diminish significantly the sources of such pressures. School boards that invariably push visibly pregnant teachers out of the classroom need not worry that their constituents will first grow accustomed to seeing pregnant teachers at school and then discover that no ill effects ensue; custody agencies that always break up motherless families need not fear that their constituents will first grow accustomed to having such families in their community and then, seeing no ill effects, come to welcome them. Although the wellsprings of old fears and hatreds may have drained away, they appear to have been replaced by a carefully designed inertia.

Building an alternative consensus strong enough and concrete enough to generate political change requires a process of learning from shared experience. Institutions that are in a position to preserve their habitual ways of doing things-their "standard operating procedures"-by cutting off such experience at its source, much like legislatures that can forestall their own reform by resisting reapportionment, ${ }^{75}$ make singularly appropriate targets for a form of judicial activism that is designed to jar systematically unresponsive agencies into a more open posture.

But candor requires a concession that the theoretical underpinnings of such activism are far from complete. Insofar as the case for such activism is grounded in the instrumental argument that ad hoc decision-making will "better" protect fundamental rights in periods of moral flux, it is clear neither how varying degrees and forms of protection are to be comparatively evaluated nor how one is to assess the argument's implicit predic-

74. See note 77 infra.

75. See Lewis, Legislative Apportionment and the Federal Courts, 71 HARv. L. Rev. 1057 (1958). Note also the parallel to executive officials who can defuse pressure for a law's repeal by enforcing it only rarely, see A. Bickel, note 54 supra at 152 , or only against groups too powerless to cause effective opposition, as is arguably the case whenever all but such groups can quite readily escape a law's thrust. $C f$. Roe v. Wade, 410 U.S. 113 (1973) (invalidating state controls over early abortions; pressure for liberalization beyond the first few states may have been greatly reduced by the ability of middle-class women to obtain lawful abortions by traveling to one of the "liberal" states). 
tions about bureaucratic behavior. And insofar as the case for such activism is grounded in the noninstrumental argument that an ad hoc process of decision is required and a rule-bound process forbidden because of the intrinsic characteristics of each in situations of moral flux, it is unclear how the premises of that argument (about the importance and the entailments of communal and fraternal aims) are to be connected with constitutional discourse of a sort appropriate for judicial pronouncement. ${ }^{76}$ Rather than terminating the discussion because of these (potentially unfillable) gaps, I would invite the interested reader to press on; recognizing that the foundation is yet to be completed, we might nonetheless learn something of value from exploring alternative superstructures.

\section{Two Doctrines? One Doctrine? No Doctrine?}

Given the basic arguments thus far advanced in behalf of what might otherwise seem a rather bizarre type of judicial intervention, at least two major doctrinal formulations seem possible. The first, triggered by a court's combined perception of moral flux and systemically unresponsive institutions affecting fundamental rights, would hold that law and policy in the perceived area of transition must be developed on an individualized, caseby-case basis, unconfined by rules of thumb inherited from the prior era. ${ }^{77}$ At least some aspects of childhood and of children's roles in contemporary American society-for example, sex roles, economic roles-seem to involve precisely the sort of moral flux this first formulation requires; as to such aspects, the doctrine would point to individualized determination of at least some child-related controversies involving fundamental rights. Indeed, to the extent that the need to keep individual decisions affecting such rights unencumbered by antiquated change-resisting rules is thought to underlie the doctrine in the first instance, it seems at least arguable that the old rules of thumb cannot be retained even as rebuttable presumptions

76. It is therefore obvious that the fuller development of the theory sketched here must await a later work; but we have already seen, in the parallel structure of the Stanley and LaFleur situations, the rudiments of a significant and, indeed, exciting basis for active judicial intervention, even on the premises of mainstream democratic theory, in settings likely to occur with growing frequency in the modern bureaucratic state. It should be added that the argument developed here as an account of Stanley and LaFleur does not purport to reflect anything of the Supreme Court's own motivations. I have been far less interested in why the Court has recently fastened on the "irrebuttable presumption" device than in when, if at all, the use of such a device might be justified.

77. Note that the requirement of "systemically unresponsive institutions" could be dispensed with if one accepted the noninstrumental argument that individualized decision is required for its own sake in such areas. It is largely the difficulty of couching that argument in classical constitutional terms that leads me-at least tentatively-to include the variable of bureaucratic unresponsiveness in the doctrinal formulation set forth above. 
- a conclusion that goes well beyond the Supreme Court's own decisions in this area. ${ }^{78}$

Now that we have returned to childhood as our central illustration, a second doctrinal formulation also seems plausible enough, at least initially, to merit consideration. More traditionally than through the trigger of perceived moral change, and even in the absence of peculiar institutional inflexibility, a prohibition against irrebuttable presumptions affecting children in particular might conceivably be derivable simply from the status of children as a group sharing most of the characteristics of a discrete and insular minority, while having needs so special as to make the goal of a "child-blind" society quite unthinkable. A halfway constitutional position for children as a "semi-discrete minority," and for childhood as a "semi-suspect classification," could thus take the form of a rule that all age-based lines ${ }^{79}$ and all governmental allocations of responsibility or opportunity dependent upon the circumstance of youth are "semi-suspect" in the limited sense that there must be an opportunity, absent strong justification for denying it, ${ }^{80}$ for a child to rebut any implied or asserted age-based incapacity. Unlike a rule treating age as a fully suspect criterion, which would result in completely invalidating all but the most compellingly justifiable age-based lines, the suggested doctrine would have the effect only of making such lines ordinarily permeable to rebuttal; judicial suspicion would, in effect, focus not on the legislative act of making childhood relevant-an act as consistent with genuine concern as with stereotyped contempt-but rather on the act of making childhood conclusive. The doctrine would thus preserve childhood as a legal category, with the concomitant protections typically flowing from such categorization, ${ }^{\mathbf{8 1}}$ while creating a way out for the unusually mature, capable, or independent young person.

78. See cases cited in note 9 supra. See also Note, The Irrebuttable Presumption Doctrine in the Supreme Court, 87 HARv. L. Rev. 1534, 1554 (1974). Moreover, although the Court has insisted in this area that "the Constitution recognizes higher values than speed and efficiency," Stanley v. Illinois, 405 U.S. 645, 656 (1972), its "irrebuttable presumption" decisions are open to the interpretation that individualization will not be required-even when the "irrebuttable presumption" doctrine otherwise applies-if the individual interest at stake is insufficiently weighty or if individualized hearings would not enable the government to promote its interest (including perhaps the interest in uniformity even at the expense of some flexibility) adequately. See, e.g., United States Dep't of Agriculture v. Murry, 413 U.S. 508, 518 (1973) (Marshall, J., concurring). See also note 24 supra.

79. Lines based on old age rather than on youth would require a separate analysis but would probably support a similar conclusion in light of the widespread tendency to discount the future more heavily than most persons would, in the abstract, consider desirable. See note 6 supra. Cf. Murgia v. Commonwealth of Mass. Bd. of Retirement, 376 F. Supp. 753 (D. Mass. 1974) (overturning the State's mandatory retirement provision for police officers). But see McIlvaine v. Pennsylvania, 415 U.S. 986 (1974) (dismissing a similar challenge for want of a substantial federal question).

80. See note 78 supra.

81. One must, of course, be alert to the risk that supposed "protections" are in reality something else. 
This second doctrinal formulation is of special interest here because, if it were accepted, it could diminish the need for the more elaborate and complex "moral flux" theory we have been developing; there may, after all, prove to be many "semi-discrete" minorities, including most of those persons-unwed fathers and pregnant women among them-likely to be stung by irrebuttable presumptions. My conclusion, however, does not allow me this easier path; although the most obvious objections to the second doctrine seem answerable, other objections to it, as we shall see, seem decisive.

The second doctrinal formulation might initially be thought to go too far in areas where the values of retaining any age-based lines at all would be substantially lost, and with insufficient countervailing gain, once an opportunity for rebuttal became mandatory whenever a court was unconvinced that dispensing with rebuttal would be compellingly justified. Consider, for instance, a jurisdiction that makes some form of schooling compulsory until the age of eighteen. The value of an age-based line here seems clear enough: It avoids the pain of severely invidious distinctions, protects a private sphere that might otherwise have to be pierced involuntarily for intensive inquiry designed to discover who "needs" more education, and draws a safe boundary beneath possible programs of coerced adult indoctrination. Perhaps the second and third aims could be preserved even if individual persons under the age of eighteen were permitted, at their own option, to offer evidence to rebut their presumed need to remain in school; but the first aim quite clearly could not. That very fact could, however, be offered as a "compelling justification" for denying the chance to rebut. A conceivable problem is that little would be left of the doctrine itself once that sort of justification had been accepted as sufficient. But there is no doubt that something would be left. For example, a governmental rule automatically denying junior college admission to all persons under the age of eighteen, however well-qualified and well-prepared they may be and however easily such qualities might be established in particular cases, substantially serves no aims-other than those of economy and administrative convenience, which always tend to be served by irrebuttable rules-that an opportunity for rebuttal would frustrate. Under the second doctrinal formulation sketched here, such a rule would thus be regarded as an unconstitutional conclusive presumption and would have to give way to individualized hearings-as a federal district court in fact recently held in the case of a sixteen-year-old whose General Education Examination indicated that he had achieved the equivalent of a high school education and who could convincingly show that he would be able to benefit from what a state junior college had to offer. ${ }^{82}$

82. Miller v. Sonoma County Junior College, F. Supp. (N.D. Cal. 1974). Unlike the case of hearings to avoid an irrebuttable age-based ceiling on a compulsory education requirement, hearings to circumvent an irrebuttable age-based floor on access to a public educational resource would appear to create no substantial risk of severely invidious dis- 
But there is a more serious-and probably fatal-objection to the second doctrine. Invalidating age-based irrebuttable presumptions on so broadly applicable a ground leaves the legislative and administrative processes with unacceptably little flexibility in accommodating conflicting ends and allocating scarce resources among analogously underrepresented interests. For every "qualified" sixteen-year-old who enters junior college after a special hearing, the state might argue, there will have to be an admittedly less qualified but probably more needy eighteen-year-old (more eighteenyear-olds have families and need jobs requiring further education) who is excluded. If those under eighteen years of age form a semi-discrete minority, why not the needy? Moreover, the resources consumed in the very process of holding individualized hearings might more usefully have been expended in adding to the state's basic capacity to educate larger numbers of students; and are not the undereducated a semi-discrete minority as well?

If courts are to deny legislatures and other governmental institutions the power to act upon premises such as these, the legitimacy of their intervention will thus have to turn on more than a claim that a "semi-suspect" criterion like age warrants judicial intrusion-not least because the resulting controversies will ordinarily implicate not one minority, but many. But the use of a criterion like youth, when coupled with a plausible demonstration that the line drawn irrebuttably by government (1) operates to abridge or burden an interest that adults would find protected as a basic liberty and (2) has been drawn in an area of changing norms (especially if drawn by an agency capable of frustrating the emergence of a new consensus), ${ }^{83}$ could quite plausibly suffice to legitimate judicial interference of the form discussed in this article-even where the claims of liberty-abridgment,

tinctions. The sixteen-year-old who cannot establish at a specially requested hearing that he or she is as able to benefit from college-level instruction as are most eighteen-year-olds and some persons under the age of eighteen years is not stigmatized in the same sense or degree as is the sixteen-year-old who is unable to disprove at a special hearing the proposition that, unlike the average eighteen-year-old and some persons under the age of eighteen years, he or she is still in need of mandatory education. Thus, the irrebuttable floor on access is harder to justify in terms of avoiding adverse effects of hearings than the irrebuttable ceiling on compulsion seems to be. On the other hand, the irrebuttable floor on access is arguably less offensive inasmuch as (1) it involves no coercion, and (2) it may be defended as a roughand-ready way of allocating scarce public resources. See Dandridge v. Williams, 397 U.S. 471 (1970). See also San Antonio Independent School Dist. v. Rodriguez, 411 U.S. 1 (1973). Some-but not much-indication that the Supreme Court would regard these two ameliorating circumstances as insufficient to warrant dispensing with hearings is provided by that Court's insistence on individualization in the food-stamp-eligibility context. See United States Dep't of Agriculture v. Murry, 413 U.S. 508 (1973) (arguably distinguishable because basic needs were there involved, see note 28 supra, and because power over them: had there been delegated uncontrollably to the wealthy taxpayer who, by declaring as a dependent someone over eighteen years of age, rendered ineligible for food stamps the entire household in which the "dependent" thereafter lived).

83. See note 77 supra. 
moral flux, and consensus-frustration are less convincingly established than they would have to be (under the first doctrinal formulation) outside the context of an age-based line. ${ }^{84}$ What could emerge would be a third doctrine-one to the effect that, absent compelling justification, agebased (and analogously "semi-suspect") lines must be open to rebuttal in settings arguably involving both (1) the deprivation of liberties ordinarily deemed fundamental and (2) the presence of moral transition-at least if coupled with self-preserving institutional unresponsiveness.

What sort of justification might be compelling enough to warrant denying the opportunity to rebut? Not, surely, the "scarce resources" argument, which would obviously kill the doctrine-along with much of constitutional law-altogether. But given, for example, an inquiry into a particular child's maturity and ability to lead an independent life, serious disruption of an ongoing family, if shown to be likely as a factual matter, would appear to be the classic illustration of an adequate reason to forego rebuttal. ${ }^{85}$

84. Compare the somewhat analagous argument for a "sliding scale" approach to strict judicial scrutiny in equal protection cases. Vlandis v. Kline, 412 U.S. 441, 458 (1973) (White, J., concurring); San Antonio Independent School Dist. v. Rodriguez, 411 U.S. 1, 98-99 (1973) (Marshall, J., dissenting). See Michelman, The Supreme Court, 1968 Term-Foreword: On Protecting the Poor Through the Fourteenth Amendment, 83 HARv. L. REv. 7, 20, 33-35 (1969).

85. But cf. Reed v. Reed, 404 U.S. 71 (1971). Too often, considerations of this sort have been given such overwhelming weight that the potentially oppressive and dominating character that families (like other groups with at least partially forced membership and a hierarchical structure) may display is ignored altogether. The reality is that families may threaten the autonomous growth and expression of their members and the authentic evolution of shared understandings and values at the same time that they protect such autonomy and authenticity from external interference. Yet, in case after case, the United States Supreme Court has perceived an issue as involving only the autonomy of the family and the limits of state intrusion into its freedom of choice when a more sensitive inquiry might have perceived instead a clash within the family and a consequent necessity for public choice between parental domination and the autonomy of the child as a person and as a member of alternative groups. See notes 13 \& 14 supra.

In denying that the child is "the mere creature of the State," the Supreme Court in Pierce v. Society of Sisters, 268 U.S. 510, 535 (1925), conspicuously passed over "the right of the child to influence the parents' choice of a school," $i d$, at 532, which the Society of Sisters had pressed as one ground of relief from a state prohibition of private school education, and seemingly opined that the child is entirely the creature of "those who nurture him and direct his destiny" and, therefore, "have the right, coupled with the high duty, to ... prepare him for additional obligations." Id. at 535. See also Rowan v. United States Post Office Dep't, 397 U.S. 728 (1970); Ginsberg v. New York, 390 U.S. 629 (1968). And the Court's approach in Wisconsin v. Yoder, 406 U.S. 205 (1972), nearly half a century later, was of a piece with that in Pierce. For in upholding the right of Amish parents under the first amendment's free exercise clause to keep their children out of public schools after the eighth grade, a majority of the Justices was plainly more concerned with the parents' ability to prevent their adolescent children from being exposed to "attitudes, goals, and values contrary to [parental] beliefs," $i d$. at 218, than with the opportunity of children themselves to develop independent life styles and to pursue options potentially at odds with the views and aspirations of their families and religious mentors. As Justice Douglas observed in dissent, allowing the Amish parents a religious exemption operated "to impose the parents' notions of religious duty upon their children." Id. at 242. And although the Justice would have protected the child's rights to the extent of allowing the state to prosecute those parents whose children's views 
The questions left unanswered by this discussion are not easy ones. How can courts reliably identify periods of moral flux and normative transition? How can they accurately discern systemic unresponsiveness? How sure-or even hopeful-can we be in periods of moral change that the decision-makers to whom we entrust discretionary power-often the very decision-makers whose unresponsiveness helped justify judicial intervention-will act in greater harmony with emerging norms, or more justly, than they did under the old regime? How can the underlying cohesiveness of a family-and hence the costs of risking its possibly irreversible disruption by inviting rebuttal of age-based assumptions-be reliably assessed without seriously disrupting the family in the very process of making the assessment? What sort of showing ought to count as a rebuttal to a "charge" as elusive as "immaturity"?

Many of these questions seem unanswerable at present; all the more reason for tentative, ad hoc approaches-even to the task of deciding when

had not been canvassed, even he stopped short of vindicating the possibly independent perspective of the child in the lawsuit who had merely indicated in the most general and inconclusive way "that her own religious views are opposed to high-school education." Id. at 243 .

One should not be misled into believing that the Supreme Court's jurisprudence has made even a child's considered expression of religious views dispositive of the state's power to interpose its will. On the contrary, in sustaining over religious objection the child-labor conviction of Sarah Prince, in Prince v. Massachusetts, 321 U.S. 158 (1944), the Court gave virtually no weight to the fact that testimony by the nine-year-old girl Betty whose distribution of religious literature in the company of Mrs. Prince gave rise to the latter's prosecution "was offered at the trials, and was excluded, to show that Betty believed it was her religious duty to perform this work." Id. at 162-63. One might disagree with Justice Murphy's dissenting assessment in Prince that the state had "completely failed to sustain its burden of proving the existence of any grave or immediate danger," $i d$. at 174 , to the child or the community sufficient to restrict the religious freedom there at stake, but one must at least recognize that the Court in cases like Prince and Yoder has never paused to consider adequately the independent claims and interests of the children involved, perceived as persons in their own right.

The solution, however, cannot be for the state to intervene routinely or casually between parent and child. In the seminal case of Meyer v. Nebraska, 262 U.S. 390 (1923), which the Supreme Court in Prince, some two decades later, significantly described as having guarded "children's rights to receive teaching in languages other than the nation's common tongue," 321 U.S. at 166 (emphasis added), the Court had recalled that children in Plato's Republic were to be raised outside of any family structure so that "no parent [would] know his own child, nor any child his parent," 262 U.S. at 401-02, and that Sparta, "[i]n order to submerge the individual and develop ideal citizens, ... assembled the males at seven into barracks and intrusted their subsequent education and training to official guardians." Id. at 402 . The point, of course, is that some form of "family" as a focal point for human feeling and solidarity has been perceived in virtually every society as a latent counterweight to central authority. Thus, in denying to the state any "general power . . . to standardize its children," 268 U.S. at 535, the Pierce Court, like the Court in the earlier Meyer case and the Court in the more recent Yoder case, quite naturally looked to the family as a constitutional buffer between the individual and the state. In historical periods when families may thus be relied upon to protect the autonomy of children, this general approach has much to commend it. But it is obviously no easy matter to characterize the place of "family" in our own time and culture, a characterization without which no confident assertion can be offered as to the direction in which judicial intervention should tilt. See generally R. NisBet, The Quest For Community (1969). 
the time has come for courts to act along the lines sketched here. A noncontroversial formula for detecting disintegrating consensus, after all, seems a contradiction in terms. Partisans can hardly be trusted to weigh the degree to which departures from "mainstream" views represent mere aberrations, as opposed to basic inroads on the very existence of a widely shared center. Nor do the doctrines here sketched purport to explainlet alone justify-more than a few of the Supreme Court's decisions invalidating conclusive presumptions. ${ }^{86}$

Indeed, it seems doubtful that the concept of "doctrine" can properly apply to anything so loosely structured, so ambiguous, and so tenuously -even if intriguingly-anchored in established constitutional theory as the mode of analysis suggested here. For the very character of the argument I have offered for the selective judicial invalidation of certain conclusive presumptions probably assures that such invalidation, whenever it occurs, will always appear in a transitional form-occupying a doctrine-free zone in which the Supreme Court itself exercises what will, for some, seem an uncomfortably roving discretion as a discoverer (partly, indeed, as a creator) of moral uncertainties. What emerges, therefore, both in the case of children and more broadly, is probably not a "doctrine" of irrebuttable presumptions at all, but rather an antidoctrine-a way, no doubt frought with risk, ${ }^{87}$ for courts to facilitate, and take part in, the evolution of moral -and thus legal-consciousness.

86. Possible explanations for decisions other than Stanley and LaFleur are suggested in note 28 supra.

87. Whether the risk in the end makes the entire venture ill-advised is a hard question; I am inclined, however, to the view that it does not. 